\title{
Swine at the chancery and locks to chests: dispersal, destruction, and accumulation of Sicily's financial archives in the later Middle Ages
}

\section{Alessandro Silvestri ${ }^{1}$ (D)}

Accepted: 30 September 2021 / Published online: 18 October 2021

(c) The Author(s) 2021

\begin{abstract}
In the last twenty years, anthropologists, archivists, and historians have dedicated increased attention to the study of archives as objects of research themselves. In so doing, scholars have predominantly examined the emergence and transformations of archives during the early modern age, focusing mostly on political and diplomatic depositories. They have tended to neglect financial archives, which is unfortunate, as - alongside judicial archives - they were probably the largest documentary repositories of the pre-modern world and those that first faced the problem of managing huge masses of documentation. This article discusses the formation and development of the Kingdom of Sicily's financial archives in the later Middle Ages, arguing that this repository evolved into a collecting archive by the early fifteenth-century, when it preserved not only the records and accounts produced by the central financial administration, but also those from a number of territorial officers and magistracies. This archival turn, I suggest, originated from the fact that the Crown of Aragon's rulers constantly needed increased incomes to fund bureaucracies and warfare and exercise patronage, and thus needed financial information organized, at hand, and under their control. After briefly discussing the emergence of the financial archive in the thirteenth-century, this essay traces the Crown's attempts to create a stable repository for storing financial records and accounts and its continuous struggles to prevent documentation from being scattered and dispersed. Finally, it examines the successful strategy that King Alfonso V of Aragon (1416-58), called the Magnanimous, pursued to organize financial documentation and concentrate records and accounts produced by financial administration into a stable building. The essay pays particular attention to the material aspects of preserving records, e.g., the restoration of buildings, construction of chests, and preparation of secure locks that were integral to the emergence of collecting archives for financial documents in the later Middle Ages.
\end{abstract}

Keywords Concentration · Destruction · Dispersal · Financial and accounting records $\cdot$ Kingdom of Sicily $\cdot$ Material aspects

Extended author information available on the last page of the article 
On 3 July 1790, don Onofrio Ardizzone, avvocato fiscale of the Kingdom of Sicily, updated the island's viceroy Francesco d'Acquino about the reorganization of the financial archive of the Tribunale del Real Patrimonio (Tribunal of the Royal Patrimony, henceforth: TRP), which in 1569 had replaced the medieval Magna Curia Rationum (Great Court of Accounts, henceforth: MCR) (Sciuti Russi 1983, pp 69-136). At the royal palace of Palermo 'an enormous number of writings', Ardizzone explained, were 'stored in a location that was dark and damp, as well as inappropriate for their preservation', and many of them 'lay on the floor, rotten, and whoever entered that room for conducting his business stepped on those documents'. Although authorities had been aware of this situation since the 1760s, the reorganization had not been completed. To persuade the viceroy to speedily conclude this archival enterprise, Ardizzone stressed the archive's importance:

'This is indeed the archive of the mastri razionali [i.e., the accounting masters], with whom the Aragonese princes had replaced the camerari delle provincie, whose tasks are described in the constitutions of the Norman and Swabian princes. The memory of this archive is so old that everyone acknowledges its importance, for it does not preserve writings concerning private affairs, but all those pertaining to public law whenever it affects the royal patrimony, origins of all the incomes, dismembrazioni [i.e., alienations of properties], and all the affairs conducted across centuries. It also includes all the grants and concessions of the princes that, according to the ancient decrees, it was mandatory to record' (ASPA, RS, RP, Incartamenti, B. 1166).

The oldest documents preserved at the TRP's archive were not interesting merely as objects of scholarship; they were crucial in proving the validity of any grant, payment, and transaction pertaining to the Kingdom of Sicily's royal patrimony and in providing information about their developments across centuries. Although we cannot say if Ardizzone's letter helped to accelerate the archival reorganization, it probably prevented the oldest documentation from being destroyed. After discarding the documents that were irreparably damaged, the archivists-skilled 'in the reading of old characters, rotten and eroded by time' (ASPA, RS, RP, Incartamenti, B. 1166, 3.7.1790)—carefully listed the surviving late-medieval writings in the new inventory (313 folios worth) (ASPA, TRP, NP, N. 1065 and N. 1066), and stored them in the newly built six-room repository, alongside records and accounts produced up to the eighteenth-century.

This inventory demonstrates that the MCR's repository had operated as a central collecting archive for the realm's financial administration since the later Middle Ages, revealing an earlier instance of the specialization which scholarship associates with the TRP archive in the eighteenth-century (Giuffrida 1956). Evidently, the archive preserved not only records produced by the accounting masters during the fifteenth-century, but also a striking number of writings from external magistracies and individuals, including all the accounts and papers that officers managing public money annually submitted for audit review. Such a vast documentary repository for financial records and accounts was not uncommon in the 
pre-modern world. For instance, the English exchequer was storing its records at the Tower of London by the early 1300s (Clanchy 1993) and the Catalan-Aragonese monarchs established a specific archive for financial records in Barcelona in 1318 (Conde y Delgado de Molina 2008, docs. 35, 179-180). In Italy, specialized archives for preserving financial records are attested from the decades between the late thirteenth and early fourteenth-century in many of the peninsula's polities, including the duchy of Savoy (Andenmatten and Castelnuovo 2008), the republic of Florence (Tanzini 2008), the duchy of Milan (Ferorelli 1912), and the realms of Naples (Palmieri 2002; d'Arcangelo 2021) and Sardinia (Serci, 2016). Governments' attention to preserving financial archives mirrored the period's political developments, with monarchs and other rulers-for instance, the territorial lords in Southern Italy (Senatore 2021) — constantly seeking to boost their incomes to cope with increasing costs of bureaucracies and warfare from the midfourteenth-century on. Systematically organizing financial information let them keep their dominions' accounts and finances in order even as they constantly sought a more reliable management of revenues and expenditures.

Yet despite increased scholarly attention to the history of archives and information (de Vivo et. al 2016a; Walsham 2016; Head 2019, ch. 2), the study of the financial archives that governments produced, organized, managed, and preserved across centuries continues to be neglected in favor of political (de Vivo 2013) and diplomatic (Dover 2007) repositories. Head (2019, p 15) for instance, deliberately omitted financial records from his study on early modern European archives. Among the articles on the history of archives published in the most recent anthologies (Brendecke 2015; de Vivo et al. 2015; Corens et al. 2016, 2018; Donato 2019) and journal special issues (Schwartz and Cook 2002; Blair and Milligan 2007; Head 2010; de Vivo et. al 2016b; Donato 2018), only Ann Hughes and Jacob Soll's essays are specifically focused on financial archives. Hughes (2016) shows that the regular accumulation of parish accounts at central archives during the English civil war (1642-51) resulted from both the parliament's fiscal and military pressures and the active role of local communities. In his discussion of Jean-Baptiste Colbert's policy toward the establishment of a royal archive in France, Soll (2018) shows the importance of accounting and financial records and their role-in connection with mercantile culture and commerce-in archival developments in early-modern France.

If it is true that-as these scholars demonstrate-the early-modern era had a crucial impact on the development and organization of financial archives, it is also true that many of those archives were established earlier and by the later Middle Ages had already grown into the largest documentary repositories of several polities. In this essay, I examine the emergence and developments of the Kingdom of Sicily's financial archive, discussing how monarchs tried-sometimes successfully, sometimes not - to safely accumulate and preserve financial records and accounts. I will analyze the accidental destructions or dispersals that affected Sicilian archives since the Norman-Swabian age, as well as later attempts at documentary retrieval and archival concentration. This enables me to demonstrate the emergence of a stable collecting archive for financial records and accounts under King Alfonso V of Aragon (1416-1458), called the Magnanimous, and his successors. In so doing, I aim to fill a gap in historiography. Sicilian scholarship has so far neglected the study 
of these archives, with the exception of Carmelo Trasselli (1954), who surveyed the TRP's archival holdings after the Second World War and gave a provisional order for the surviving documentation (ASPA, Inventario N. 193; also in Salamone 1997). Romualdo Giuffrida (1956), in contrast, focused solely on the late-eighteenth-century archival reordering.

More broadly, all this pertains to the current debate on the history of archives (Stoler 2002; Head 2003; Ketelaar, 2006; de Vivo 2010; Brendecke 2016), but with a focus on accounting and finances (Soll 2014, 2018), and a particular emphasis on the material aspects of archival preservation and organization, something Markus Friedrich did for the early modern era (2018, ch. 6). I suggest that the concentration of financial documentation in Sicily should be connected with the changing political needs of the Crown of Aragon-a union of territories of which Sicily was a constituent component between 1282-95 and 1409-1516-particularly with its efforts to control the island's financial resources and incomes and their distribution more closely. The Kings of Aragon-it should be noted-did not reside in Sicily and governed this realm from afar through viceroys. This royal absenteeism meant that financial archives played a crucial role in Sicilian politics and government: unsurprisingly, while reorganizing the Sicilian archival system, authorities devoted most of their efforts to concentrating, ordering, and securing financial records and accounts. Thanks to the accumulation and organization of an unprecedented amount of financial information in the island's repositories, Alfonso the Magnanimous significantly increased royal incomes. In so doing, he not only exploited Sicily's revenues to fund crucially his Neapolitan campaigns in the early 1420s and 1435-42not by chance, the financial archives' reorganization started at the same time of the first Neapolitan campaign-but to strengthen his political control over the island. Through distributing the realm's profits among the local governmental elites, the monarch and his successors acquired increasing political and economic support from their Sicilian subjects.

Moreover, by examining the Kingdom of Sicily's archival practice in the later Middle Ages, this essay suggests that, because of its size and variety, the financial repository was the archival arena that most challenged rulers. Rulers had to cope with new issues of documentary accumulation, organization, access, as well as safety and security - that is, they had to prevent the loss or theft of data and accounts. As the Crown gathered an increasing number of documents, it promoted new strategies to preserve archives and keep them organized, so that accounting officers could more easily access the documentation they needed to manage finance and audit accounts. In contrast, the island's political and administrative repositories-for instance the royal chancery and the prothonotarius' office-never evolved into collecting archives and remained attached to the offices that produced them, in accordance with the realm's traditional archival practice.

The essay is organized as follows. The first section discusses the early establishment of the Kingdom of Sicily's central archives and their total annihilation in the mid-fourteenth-century. Thereafter, I focus on the reconstruction of the island's archival system in connection with the restoration of royal authority, highlighting the various difficulties the Crown faced to keep control over financial records and accounts. The following section examines the successful strategy authorities 
pursued for the establishment of collecting financial archives and safeguarding the documentation therein preserved, with a particular attention to the material aspects of archives such as buildings and furniture. The last section provides some remarks on the themes discussed in this article.

\section{Establishment and destruction}

In ruling a realm that included both Sicily and Southern Italy (regnum Sicilie), the Norman monarch Roger II of Sicily (1130-54) had since the 1130s established central institutions at the royal palace of Palermo. The small chancery originally intended for the County of Calabria evolved into a broad organ that served the government of the entire regnum Sicilie (Takayama 1993). This evolution led to the increased production of writings and the development of different types of documents related to various aspects of administration (e.g., justice or finance), as well as - it has been argued - to the establishment of early methods of record-keeping (Enzensberger 2002). To preserve this growing number of documents, a treasuryarchive (scrinarium) seems to have been created at the royal palace in Palermo. This development not only helped Norman monarchs preserve the most important writings but allowed them to easily retrieve needed information. It is unclear if this repository evolved into a central administrative archive, as its holdings were destroyed and scattered on at least two different occasions: first when a group of rebels assaulted the royal palace in 1161 and then following the Holy Roman emperor Henry VI's (1191-97) conquest of Palermo in 1194 (Casanova 1928, p 311).

Under the subsequent Swabian rule, King Frederick II (1198-1250) restored royal archives and introduced two parallel series of registers that were regularly produced by the realm's chancery using innovative record-keeping methods. The emergence of a permanent magistracy (i.e., the MCR) dates back to the age of king Manfred of Sicily (1258-66), who entrusted it with financial affairs and the preparation of relevant documents. Although information about the Swabian archives' organization and management is scanty, their importance is paramount: a royal decree of Frederick II established that the documents' validity depended on their having been registered and preserved in the archives (Pietro della Vigna 1786, pp 119-120).

The undisputed importance of archives for governmental and administrative purposes during Swabian rule does not mean that they were central and stable repositories. A few archival sources dating to the succeeding Angevin age suggest that, after permanently leaving Sicily in the 1210 s, Frederick II relied mostly on mobile archives, including documentary repositories he established in the castles of Canosa or Lucera, which he frequently stayed on his travels across the Mezzogiorno (Casanova 1928, p 334). This archival strategy was actually a common feature of coeval European polities, which did not possess stable repositories for preserving documentation. Under King Henry II (1154-89), the English Crown continuously moved the treasury-archive "between Winchester, London, and other royal palaces, hunting lodges and fortresses" (Clanchy 1993, 163), while the thirteenth-century CatalanAragonese monarchs relied on a network of monasteries and other documentary 
repositories along the roads connecting Aragona, Catalonia, and Valencia (Silvestri 2016, 440).

The establishment of permanent central archives in the regnum Sicilie should thus be ascribed to Charles I of Anjou (1266-85) who, after conquering the kingdom in 1266, initiated a vast operation to retrieve documents and accounts pertaining to royal administration. He tasked a number of Angevin officers with searching repositories across the realm - including the castle of Melfi, where the bulk of the archivum regiae curiae was preserved under King Manfred (Capasso 2009, doc. 331) - and dispatching documentation to the royal court (Sthamer 1911, docs. 2-4). During the 1270s and 1280s, oxen, mares, and mules pulled carts loaded with chests full of writings and accounts from various localities to Naples. These chests, like the "eleven chests, full of our registers" entrusted to the chancery clerk Matteo Criniano (Sthamer 1911, doc. 13), were initially stored at Castel Capuano and in 1333, the archive was permanently moved to the palace of the royal mint (from here, archive of the royal mint) under the responsibility of the magistri rationales (Palmieri 2002). This movement toward archival centralization originated from the Angevin monarchs' need to keep at hand all documents and records pertaining to the government of their realm. These included both the growing number of records their administration produced, including five different series of registers containing transcriptions of outgoing letters (Kiesewetter 1998, pp 366-368), and all the writings produced in previous decades, including all the "registers dating back to the above-mentioned Emperor [Frederick II]" (Chiarito 1772, p 25).

Although Sicily only remained under the Angevin rule for about fourteen yearsbecoming a member of the Crown of Aragon in 1282 and an independent realm under a cadet branch of the Catalan-Aragonese dynasty in 1296-Angevin developments in record-keeping and archiving deeply influenced the island's approaches to organizing, preserving, and storing documentation. As in Naples, a system of parallel series of registers was established: in addition to the royal chancery records, the series of the prothonotarius and the magistri rationales, which-in book forms that are like chancery registers-,respectively included letters and privileges related to grants of offices, fiefdoms and other goods, and documents pertaining to payments and finances. To preserve this increasing output, Sicilian monarchs restored the realm's independent archives - attested since at least the 1290s (La Mantia 1918, doc. CXCV)—and located at the royal palace of Messina from the 1330s on. These archives, as shown by a later record dating to 1357, preserved "all the archives or books of accounts pertaining to all the offices of the realm", namely the royal chancery, the MCR, and the judicial administration (Giardina 1937, doc. XL). This means there was no single archive, but rather a multi-archival system that included several documentary repositories under the responsibility of the magistracies that produced them. Unlike the other central organs, the accounting tribunal of the MCR amassed in its archives not only records compiled by its own staff, but documentation produced by other officers, namely all the accounts, reports, and other relevant documents the accounting masters needed to administer the realm's finances and to audit accounts.

Unfortunately, at this stage it is impossible to investigate in greater detail the archival practices of the Kingdom of Sicily. In 1356, during the siege and occupation 
of Messina, the Angevin troops set fire to the royal palace and, as a result-as Frederick IV of Sicily (1355-77) recounted- "all the registers of our chanceries preserved in the palace of the noble city of Messina were burnt" (La Mantia 1918, p XLII). By the mid-fourteenth-century, the entire archival memory of the Kingdom of Sicily had been completely annihilated, as the fire likely destroyed all documents and records produced by Norman, Swabian, and Angevin administrations. Destructions of this kind were typical of the period: e.g., the chancery records' fire in Dublin (1304) (Crooks 2013, 390), and the financial archives' flood in Naples (1336) (de Vivo et al. 2016c, cap. III, doc. 36/a), and arguably were a stimulus for authorities, who started paying increasing attention to the archives' organization and safety.

\section{Reconstruction and dispersal}

Following the death of Frederick IV, the Sicilian aristocracy took direct control of the island (1377-92), causing the collapse of royal structures. After the royal authority's restoration in 1392, the new monarch Martin I of Sicily (1392-1409) and his father Martin of Montblanc-who de facto ruled on behalf of his young son-thus immediately promoted the reconstruction of the kingdom's institutions. King Martin I maintained the governmental seat at the Castello Ursino of Catania, where his predecessor had transferred the court after the Angevin occupation of Messina. Possibly because of the scarcity of surviving records-only a few registers of Frederick IV's rule survived - the monarch seems to have initially relied on mobile archives that he carried on his frequent travels across the realm. In a period when Martin I was trying to impose political control over the island and crush aristocratic rebellions, mobile archives were practical, as they allowed him to retrieve needed records and documents, for instance, to distribute royal favor's or organize military deployment.

Once royal authority was fully re-established-between 1396 and 1398-the new documentary repositories of Castello Ursino grew significantly, as documents and records produced by the various central administration's chanceries increased. Apparently following pre-existing archival tradition, each central office producing royal documents (privileges, letters, mandates) transcribed them in its series of registra and preserved them in its own repositories. Further proof of this multiplearchive strategy can be seen in a plea from the city of Messina to the monarch in 1396 that the management of the realm's central archives be returned to it. The appeal said that "the archives of the great court [i.e., the judicial organ] and of the accounting masters have to be preserved in Messina as it used to be in ancient times, alongside all the other archives" (Giardina 1937, doc. L), namely the documentary repositories of the royal chancery and of the prothonotarius' office. Although the monarch assented, documents and records produced by central administration never returned to the royal palace of Messina, instead accumulating at the Castello Ursino of Catania. The frequent transfer of archives from one place to another, therefore, did not stop even when monarchs established stable repositories, for they often moved documentation according to their changing administrative and political needs. Indeed, the mobility of theoretically stable archives was not unique to Sicily, but a common trend among various late-medieval polities. In fourteenth-century Ireland, 
for instance, the English government initially concentrated the chancery rolls at the Dublin castle's Bermingham tower (1309), then transferred all documents pertaining to the exchequer and the common bench to Carlow (1361), then, by the end of the century, back to Dublin (Crooks 2013).

Although Sicilian sources clearly attest to the frequent transfers of archives and documents, they do not give details of exact archival practices. A second plea from Messina in 1399 - again accepted by the monarch, but never put into practiceseems to suggest that all the officers in charge of compiling registers were required to deposit at relevant archives all the registra older than five years (Giardina 1937, doc. LIV), i.e., those that were no longer needed for daily business. Therefore, despite the growing number of writings produced by central administration, archival accumulation was such a slow process that, at the beginning of the fifteenthcentury, the documentary repositories at Castello Ursino probably just preserved a few dozens of registers. This is further confirmed by the record-keeping practice of Sicily in the early fifteenth-century, which saw the royal chancery and the prothonotarius office producing one register for each administrative year (corresponding to the indictional year: 1 September - 31 August). ${ }^{1}$ In contrast, the MCR's archives followed a different archival logic, rapidly becoming a massive repository that stored different series of records produced annually by the financial chancery, as well as accounts and writings that the royal officers managing public money-like the treasurer or the clerks entrusted with tax collection-submitted to the magistri rationales to be audited, essentially creating a collecting archive of financial administration.

If through the strategical concentration of various different archives into the same building the Martins - after King Martin I died, his father Martin I of Aragon (1396-1410) inherited the island-intended to facilitate the regular use of records for administrative purposes and to prevent documentary losses, it is nonetheless true that the massive dispersal and destruction of royal writings and records suggests that this archival program did not work as expected. The main issue was probably the tendency of officers to preserve documentation at their private residencies. This was not just negligence: some chancery officers and secretaries regarded registers as a source of income, as they charged for issuing copies. The events pertaining to the chancery registra of the Martins' age is emblematic. In 1397, Antonio Bifaro, a clerk and later lieutenant of the royal chancery, was entrusted with the task of "recording, keeping, preserving, and managing the registers and other writings of the chancery" (ASPA, RC, R. 28, f. 136v, 10.1.1397). Bifaro handled this task until 1414, when Ferdinand I of Aragon (1412-16) transferred the royal chancery archive to the office's magister notarius (master notary) Federico Pizzinga (1408-17), namely the clerk legally in charge of preserving records (ACA, RC, R. 2427, f. 90rv, 17.3.1414). Yet neither Pizzinga nor his successor Giovanni Vitillino (1417-34) could retrieve the royal chancery archive, which remained in the possession of Antonio Bifaro's heirs in Castroreale, a small town in the Sicilian hinterland, about 30 miles from

\footnotetext{
1 The indiction was a period of 15 years that several medieval chanceries used for dating documents. However, the beginning of the indictional year varied from place to place. Following the Papal example, the Kingdom of Sicily used the so-called Greek style, with each indictional year starting on 1 September.
} 
Messina. This archival odyssey only ended in 1454, when the master notary Antonio Giacomo Speciale finally took possession of the chancery registers in Messina, where they were temporarily transferred in 1440 (Silvestri 2018, pp 406-408).

Though authorities and various chancery clerks successfully retrieved the registra cancellarie - still preserved today at the State Archives of Palermo- the stories of many coeval financial records and accounts ended less happily, with only a few records and accounts surviving from the period. Unlike chancery records, accounts were not a source of incomes, and the officers who produced them were less careful about their preservation. Although Martin I immediately entrusted the management and organization of the magistri rationales' archive to an archivarius-first the Catalan Joan Esquerdo (1392-97), later the Sicilian Antonio di Giovanni (1397-1406) and Antonio Ursone (1406-17) (Silvestri 2018, p 416)—many writings were thus never stored at Castello Ursino. This is demonstrated by archival sources dating back to the 1440s, when a vast inquiry on the previous financial administration of Sicily took place. King Alfonso the Magnanimous ordered various Sicilian officers to retrieve accounts and documents of the Martins' age from various individuals, including the "libri de li cunti" (books of accounts) in possession of Betta, wife of the above-mentioned Antonio Bifaro (ACA, RC, R. 2894, f. 22r, 8.7.1444), and the quaterni held by the heirs of Nicolò Sottile, who had administered the customs office of Palermo (ACA, RC, R. 2894, f. 25r, 8.7.1444). As late as 1465, under John II of Aragon (1458-79), the Sicilian viceroy ordered all those individuals who possessed "registers of the previous princes and monarchs, as well as those of the lady Queen Blanche"-the wife of Martin I, Blanche ruled Sicily during the interregnum (1410-12) — to return them to the royal court, because "for not being well preserved and stored, they are going to be dispersed and ripped apart" (Gregorio 1791-92, II, p 430).

But the disappearance of the financial archives cannot be ascribed solely to the failure of the Martins' archival strategy; there were also later destructions and dispersals. Sources attest that circa 1410-12 Bernat Cabrera set fire to Catania's chancery-perhaps because papers there indicated that his possession of the wealthy County of Modica was illegitimate (Barberi 1962-63, I, p 29) - which destroyed many writings and papers preserved there, probably including accounts and registers of the magistri rationales, who seem to have used the chancery as their workplace. Authorities promoted the restoration of Catania's royal chancery in 1413 (ASPA, RC, R. 49, f. 24r, 9.5.1413) and 1437 (ASPA, TRP, NP, N. 67, f. 47r, 26.3.1437), purchasing new tables for the accounting masters, storage chests, and locks for securing the archive. But Castello Ursino experienced a gradual deterioration, particularly after the seat of central administration was moved to Palermo in the early 1420s. In 1461, the accounting master Giacomo Bonanno reported that swine and sheep at Catania's chancery had entered the building and caused "the destruction of walls and doors" and possibly other damages, which he asked to have acknowledged immediately (ASPA, TRP, NP, R. 486, f. 44v, 13.1.1461): we can speculate that these other damages related to documentary losses. After all, archival sources attest that the magistri rationales used Catania's chancery during their stays in Eastern Sicily and kept various records and accounts there, most of which were lost in an arson attack in 1514 (ASPA, RC, R. 230, ff. 829v e 831rv, 30.4.1514). 
While these archival dispersals and destructions compromised the integrity of the MCR's archives, the major losses can probably be ascribed to the above-mentioned inquiry on Sicilian finances. This inspection, which had initially started as an investigation of viceroy Nicola Speciale's administration (1423-32), resulted in the massive transfer of records, accounts, and other documents from the magistri rationales' archives of Palermo to Messina-where Alfonso the Magnanimous was holding his court in winter 1434-where they could be examined by the general accounting master of the Crown of Aragon Bartolomé Scayo, who was in charge of the investigation (ACA, RC, R. 2892, f. 31r, 7.1.1434). After King Alfonso conquered Southern Italy and transferred his royal court to Naples, all those documents were probably transferred to the mainland along with those of the Martins' age and vanished. It is possible that this Sicilian documentation was moved to Barcelona in 1467 alongside the Alfonso's archive (López Rodríguez 2018, p XXVIII) and was lost in the seventeenth-century, or that it remained in Naples, where it could have been destroyed by any of the various archival disasters of the early modern era. The hypothesis that the bulk of financial documentation produced between the 1390s and the 1420s was lost at the same time is further supported by the fact that the records and accounts listed in the above-mentioned eighteenth-century inventory are continuous only from the mid-1430s on: that is, after the financial inquiry. By that time, however, the Crown had already begun concentrating all the archives in Palermo, including a specific repository for financial records and accounts.

\section{Accumulation and preservation}

Starting in the 1420s, the Crown moved the seat of central administration to the so-called Hosterium or Steri palace of Palermo. This decision was made for both ideological and practical reasons. As explained by King Alfonso the Magnanimous in 1436, the building not only symbolized royal authority, but facilitated the island's administration. Sicilian viceroys - the legitimate representatives of the monarchwere supposed to live and keep their court at the Steri "and nowhere else" and to use the building as the official seat for managing all affairs related to the realm's financial, judicial, and political administration (ACA, RC, R. 2890, f. 34r, 31.8.1436).

As a result of this administrative concentration, the archives were moved to Palermo and stored in the Steri or structures attached to it. According to the traditional multi-archival system of the island, the master notaries of each magistracy, like the expert and accountable prothonotarius's master notary Bono de Mariscalco (1404-39) and the royal chancery's master notary Giovanni de Vitillino (1417-34), managed and organized all the records and documents produced or received by its office. In 1438, the administration of the judicial magna regia curia archives also moved to the office's master notary, when the royal court sold Andrea Carioso (1415-48) the previously independent position of archivist, while new master notaries managed the archives of the court of appeal (sacra regia cosciencia) and the commissarii (i.e., ad hoc judges) (Silvestri 2018, ch. 13).

Given the exceptional complexity of financial archives and the striking quantity of documentation preserved therein, the MCR's master notary traditionally delegated 
the archival tasks to another clerk of the office: for instance, "by choice and decision of the master notary" Filippo Viperano (1399-1434), the clerk and archivist (archivarius) Matteo Ansalone had been entrusted "with preserving the great court of accounts' documents and records" since 1417 (ASPA, CR, N. 7, c. 244r, 5.8.1419). In turn, once appointed as a magister notarius (1438), the same Ansalone transferred the archival duties to Guglielmo Bankerio (Silvestri 2018, pp 421-424), the MCR's first notary (primus notarius). The devolution of archival duties to another clerk was essential, given how overloaded the MCR's master notary was: he supervised the financial chancery, assisted the accounting masters during audits, and personally managed current registers and all writings useful for daily activity.

It was de facto impossible for the MCR's master notary to administer the financial archive in person, as it needed a specific clerk or archivist fully dedicated to its management. The officer in charge had to continuously retrieve all the writings the magistri rationales needed to conduct audits and manage an ever-growing number of records and accounts that, in the fifteenth-century, were stored in the financial repository according to standardized practices of record-keeping and documentary accumulation in order. The financial chancery annually produced registra series composed of hundreds of pages that the MCR acquired from booksellers and binders (e.g., ASPA, TRP, NP, N. 486, f. 2r, 5.9.1460) - and into which it transcribed ongoing letters, privileges, and mandates: at least two registers a year of lettere viceregie (ASPA, Inventario N. 73/D), including payments and other financial writings produced by request of viceroys (records that were then organized in the volumes' different sections, like castles or debts); one register a year for both the series lettere patrimoniali and lettere citatoriali (ASPA, Inventario N. 193), which contained letters related to Sicilian finances but that originated from the MCR; various volumes and writings pertaining to judicial activity, including three different series of Atti (ASPA, Inventario N. 73/B), Effetti pendenti, and Scritture pendenti (ASPA, Inventario N. 73/D) each volume of which covered a few years.

At the same time, the MCR annually received various accounts (quaterni) and writings from officers entrusted with collecting and spending incomes on behalf of the Crown. Some of them-the treasurer, the magister portulanus, the magister secretus, as well as the secreti of Catania, Malta, Messina, and Palermo-were legally required to submit their accounting books (quaterni) to the MCR a few months after the administrative year ended (see Table 1), along with all other writings the accounting masters needed to review accounts (e.g., mandates to verify the legitimacy of financial transactions or receipts to check the accuracy of the royal taxes' management). In addition, these officers periodically submitted summaries of their ongoing incomes and expenditures (informationes), at a pace that significantly increased after the reform of 1460, with the treasurer and Palermo's secretus forced to update the magistri racionales about their transactions every fifteen days.

This increasing flow of informationes reflected the authorities' need to control strictly the realm's financial management, thus preventing potential embezzlements. Thanks to this development, the accounting masters de facto constantly monitored incomes and expenses of the main magistracies managing public money, using this accounting information as a crucial term of comparison with the quaterni submitted to the MCR few months after the end of the indictional year. 
Table 1 Recurrence and deadlines for the submission of informationes and accounts to the $M C R$ before and after 1460 (Raymundettus, 1574-76, Vol. II, Tit. VIII, Pr. IV, 88-89)

\begin{tabular}{llllll}
\hline & \multicolumn{2}{c}{$\begin{array}{l}\text { Recurrence of the } \\
\text { informationes' sub- } \\
\text { mission }\end{array}$} & & $\begin{array}{l}\text { Deadlines for the } \\
\text { quaterni' submission }\end{array}$ \\
\cline { 2 - 3 } \cline { 5 - 6 } Officers & Pre-1460 & Post-1460 & & Pre-1460 & Post-1460 \\
\hline Treasurer & 4 months & 15 days & & 4 months & 4 months \\
Magister Portulanus & 4 months & 1 month & & 3 months & 4 months \\
Magister Secretus & 4 months & 1 month & 3 months & 4 months \\
Secretus of Catania & 4 months & 1 month & 3 months & 6 months \\
Secretus of Malta & 4 months & 6 months & 3 months & 1 year \\
Secretus of Messina & 4 months & 1 month & 3 months & 6 months \\
Secretus of Palermo & 4 months & 15 days & 3 months & 8 months \\
Other officials & 4 months & 15 days & 3 months & 2 months \\
\hline
\end{tabular}

In essence, the MCR annually compiled five or six registers and received about seven books of accounts that were kept at the financial archive, for a total of at least 12 or 13 volumes yearly, in addition to various other records and loose writings. Moreover, the archive received accounts and information produced by other officers operating on behalf of the royal court (e.g., tax collectors), as well as a huge number of papers from officers administering public money in the localities. The accounting masters required all these writings and accounts whenever the entries transcribed in the central officers' quaterni-which included information on the royal patrimony's management at the local level - appeared to be inaccurate or suspicious, or when the submitted accounts did not correspond with information in their archives. Although it is difficult to indicate the exact number of writings the MCR required for conducting further investigations, it is certainly a massive number, given the lists of the documents requested, which were methodically inscribed in the quaterni's margins, alongside the relevant entry.

The Kingdom of Sicily's financial archives were fundamental for the Crown for more than just facilitating accounting revision or verifying the accuracy of subjects' rights and privileges. The accumulation of financial knowledge in a single repository meant that Alfonso the Magnanimous and his Sicilian viceroys had easier access to information and thus could better organize the collection and distribution of financial resources. This let them coordinate alienations of demesne lands and rights and make significant cuts to bureaucracy thus increasing royal revenues and more efficiently allocating resources to the Crown's most urgent needs, namely the conquest of Naples (1442) and the subsequent Italian campaigns. Moreover, the Kingdom of Sicily, like other coeval polities such as the Kingdom of Portugal from the 1460s on (Head 2019, pp 80-81)-also used its funds to exercise the patronage that bought the support of local elites.

It was thus crucial to safely preserve this huge trove of financial documentation, and in 1423 the viceroy Nicola Speciale ordered Matteo Ansalone and Leonardo Bankerio to retrieve the records and writings of the MCR and the newly established financial organ called conservator maior regii patrimonii (major conservator of the 
royal patrimony, henceforth: CRP) (1414) (Silvestri 2020), and place those documents into four caxias (chests) — two for each office-which were to be transported to a chapel attached to the Palermo's Steri, the Cappella di Sant'Antonio Abate, the official seat of the new financial archive. Despite being described as "the most suitable location ... for preserving and storing the above-mentioned documents and writings" (de Vivo et al. 2016c, cap. III, doc. 28/a), this small gothic chapel was in poor condition, having previously been used to store old furniture (ASPA, SP, R. 39, ff. 25r-26r, 10.5.1422). The authorities promoted various works and restorations to transform the chapel into a suitable repository for the MCR and CRP's archives. By employing various specialized workers (builders, carpenters, blacksmiths, and keycutters), the building was provided with a mezzanine floor and new shutters-as discussed by Friedrich (2018, p 114), the windows helped ventilate the archive against dampness - and with keys, locks, and padlocks to secure doors and chests. According to a royal decree, the magistri racionales and the conservator were supposed to use the same chapel—or eventually, another room of the Steri-as the main seat for auditing accounts (de Vivo et al. 2016c, cap. III, doc. 37/a), as its direct access to the financial archive would facilitate the accounting process.

Despite sharing a building, the MCR and CRP archives remained distinct, with the latter directly managed by the conservator or by his lieutenant. They were in charge of a huge number of volumes that the CRP clerks produced annually, namely multiple series of libri (books) including six annual and two multi-year series, intended to keep the management of the royal patrimony under control: to be valid, all viceroyal letters produced by the MCR had to be recorded into one of twenty-five subsections of the CRP's books (in addition to the already existing transcriptions in the royal chancery's and accounting masters' registers) (Silvestri 2020, pp 190-195).

Unfortunately, sources give scant information about the practical organization and classificatory logic of the Sant'Antonio archives. It seems records-from both the MCR and the CRP - and accounts were placed in different chests in chronological order, with the most recent stored in lighter trunks that could be transported if necessary, and loose writings like receipts and supporting documents-probably discarded after the auditing process-placed in various bags. The oldest documentation was stored in massive chests-which were seemingly never removed from the archive-such as the "large caxia for storing the old books of mentioned conservator's office”, equipped with a three-key lock (ASPA, RC, R. 83, f. 85v, 8.8.1445) - such a lock kept the documentation safe not only from rats, but from humans. Authorities were constantly worried financial documents (e.g., tax records, accounts, etc.) could be stolen or modified, or even deliberately destroyed-as dramatically exemplified by the intentional destruction of the Duchy of Milan's financial archives in 1447 (Leverotti 2008, p 2). Therefore, in Sicily as elsewhere, the safety and secrecy of records and accounts was of the highest importance for the verification of annual accounts and therefore for the full preservation of the Crown's prerogatives and rights. In 1451, for instance, on occasion of the theft of "the large [key] to open and close the [Sant'Antonio] chapel's main door, and of the small [key] pertaining to a chest preserving book and writings of the [MCR] office", the accounting masters immediately moved to secure the archive with a sturdy new three-key lock and to provide a new key for the above-mentioned chest. Clearly, they feared that if they 
did not take action, "those books and writings stored in the chapel could be stolen" (ASPA, TRP, NP, N. 267, f. 8r, 2.10.1451).

Storing the manuscripts in chests, it should be noted, did not impede the easy retrieval of specific records or entries, which were attentively transcribed in registra, libri, and quaterni according to fully standardized record-keeping and bookkeeping methods based on the indictional year (see above, note 1). In essence, each manuscript corresponded to one single indiction-there were a few exceptions, including judicial papers - and within each volume or section of a volume, documents and financial transactions were recorded chronologically from 1 September to 31 August. Without necessarily using a repository's inventory-in fact, we do not know whether such inventories existed-the MCR's master notary/archivist could quickly find any record or entry he had been ordered to retrieve. He simply located the chest he was looking for, possibly labeled with a timeframe to ease retrieval; extracted the volume indicating on its parchment cover the indiction or years covered; then finally, searched the index at the beginning of the manuscript. If needed, he could also rely on the CRP's books, for which he was not directly responsible. Indeed, the Sicilian case study further demonstrates that the existence-or lack of existence - of an inventory should not be considered the determining factor of an archive's importance, as Andenmatten and Castelnuovo (2008, pp 347-348) suggested in their examination of the Duchy of Savoy's financial archives.

Archival sources do not give any clear information about the preservation of loose papers (annotations, mandates, quittances, receipts, etc.). We can assume that both the MCR and the CRP discarded most of these writings after having them checked, and only very few were preserved, primarily those related to ongoing affairs such as the 10 different documents (privileges, viceregal letters, receipts) pertaining to one affair and produced between 1440 and 1455, which the MCR's master notary Guglielmo Bankerio reported to the accounting masters in 1459 (ASPa, TRP, NP, N. 51, unpaginated, 13.2.1459). If loose papers were considered particularly important or would be needed in future, they were preserved and could be bound together, as with the librum informacionum (ASPA, TRP, NP, N. 51, unpaginated, 10.10.1458).

Although Sicilian viceroys had identified the Sant'Antonio chapel as the best place to manage the kingdom's financial affairs and preserve all relevant records and writings, in 1436 king Alfonso the Magnanimous_probably advised by a Sicilian informant-reprimanded the MCR's master notary for keeping the financial archive "in a place which was quite inconvenient, foul-smelling and indecent" (Silvestri 2016, 447) and urgently ordered him to secure the documentation, for the chapel was near a stable and a latrine. In the same year, "for the better preservation of the writings of the ... accounting masters and conservator" (ASPA, RC, R. 71, f. 164r, 16.12.1436), a carpenter built the chapel a solid new door, the key of which master notary Giovanni Vitillino- "and no one else"-was supposed to keep (ACA, RC, R. 2512 , ff. 75v-76r, 27.8.1436). If the door did not keep odors outside the archive, it at least prevented unwanted intrusions to the building. Moreover, records and accounts were moved into newly acquired chests for better preservation (e.g., ASPA, TRP, NP, N. 67, f. 6v, 1.10.1436).

These improvements to the Sant'Antonio archives were part of a broader archival reorganization. To give his financial personnel a more comfortable workplace, in 1443 
Alfonso the Magnanimous ordered his viceroy Lop Ximen Durrea to transfer the financial seat to the domus cancillarie or casa di la canchelleria (chancery house), located in a building in front of the Steri's entrance. The chancery house thus underwent a full restoration, with its rooms fully equipped for the administrative activity of the MCR and CRP - including desks, reams of paper, and even a green tablecloth for the main accounting masters' table (ASPA, TRP, NP, N. 51, unpaginated, 19.5.1458)—and for preserving the archives, so that they "will be well, honorably and with every essential security located and ordered" (ACA, RC, R. 2894, f. 7v, 12.7.1443). Although in 1445 the conservator and the accounting masters' seat was still at the chapel of Sant'Antonio — but in summer they met peacefully in the Steri's garden - a few years later the domus cancellarie developed into a multi-administrative hub that included the royal chancery and its archives, in addition to the realm's main financial organs and their documentary repositories, which remained distinct. While the MCR's master notary maintained his control over the accounting masters' archive, Leonardo de Bankerio- the acting conservator for about twenty years - managed "all the books and other writings and files" of the CRP (ASPA, RC, N. 103, f. 236r, 16.7.1457). Although the monarch had ordered the entire CRP archive transferred to the Sant'Antonio archives, it seems the acting conservator kept many books-probably the most recent-at his private residence, thus causing troubles and delays for the accounting process. Unsurprisingly, the magistri rationales complained that whenever they needed the conservator's books-namely, "every single hour"- they had to retrieve them from Leonardo Bankerio's house (ASPA, TRP, NP, N. 271, f. 32r, 17.2.1452).

The transfer of the MCR and CRP to the chancery house was not just a relocation. The stabilization of two fully functioning MCR archives that preserved documents related to the oldest and the most current affairs was an important development in the realm's archival practice. The dual collection can be deduced from a payment to the key cutter mastru Iohanni lu Francisci, who prepared six locks and twenty keys for the chests preserved at the Sant'Antonio archive, "where the previous years' registers and writings of the above-mentioned office of the MCR are stored", and nine locks and eighteen keys for the caxi and caxuni deposited at the chancery house, where documentation pertaining not only to the MCR, but also to the CRP and the royal chancery was preserved (ASPA, TRP, NP, N. 51, unpaginated, 18.12.1458). This meant that as they conducted their daily business at the chancery house, the accounting masters could access the old registers and accounts of the Sant'Antonio archives as needed, and they arranged huge transfers of documents between repositories when they were doing broad accounting investigations. We see this, for instance, in the transport of eighteen chests of accounts and other writings that five porters (vastasi) carried from the Sant'Antonio archives to the chancery house so they could be checked by the MCR (ASPA, TRP, NP, N. 51, unpaginated, 19.5.1459). 


\section{Conclusion}

These eighteen chests likely contained the documents the accounting masters needed to review the Sicilian treasury administration of the previous twenty years, whose accounts had only occasionally been submitted to the MCR. It was an extremely complex operation, for each entry of the treasurer's quaterni had to be compared with documents and accounts produced by various central and local officers from 1440 onward. This extraordinary investigation reveals the fundamental role of this repository in the management of the Kingdom of Sicily's finances-and therefore its government as a whole-and attests to the success of the archival strategy the monarchs initiated in 1423. Simply by storing the minimum of 12 registers and accounting books produced annually, the MCR would have accumulated at least 432 volumes by 1459 , along with several hundred letters, bundles, accounts, and various other documents that had been stored in two different buildings. This is a huge increase over the two chests initially deposited at the Sant'Antonio archive, alongside two chests containing the CRP's books, which in 1459 amounted to about 200 volumes and were seemingly all deposited at the new chancery house archive. Indeed, the establishment of financial collecting archives comes from the need to preserve the increasing flood of financial documents and make them easily available to the accounting organs' personnel. This archival strategy, however, is more than just a practical matter. Having all these writings stored in stable repositories, strengthened the control by the Kings of Aragon-who did not reside in person in the islandover financial information, letting them better manage incomes and expenditures.

Yet this unprecedented accumulation of financial records and accounts in Palermo did not produce significant innovations in terms of archival organisation and classification. Unlike treasury-archives like the Duchy of Savoy's crota, based on topographical classification (Rück 1977), or the Italian city-states diplomatic archives (Dover 2007), managing financial archives and records did not require dealing with different types of charters and documents or their specialized contents; the issue here was the huge quantity of papers that had to be preserved for present and future searches. In the later Middle Ages, this practical need led to the storage of accounts, books, and registers-in chronological order-in various, separate, probably labeled chests, specifically built to contain the greatest number of volumes. Deposited behind the archives' sturdy doors and equipped with two- or three-key locks, these chests not only kept writings safe from damp and rodents, but also from intruders looking to steal or counterfeit documents: naturally, 'the desire to secure secrecy' (De Vivo 2010, p 246) affected financial records and accounts, which could not be simply arranged and ordered on easily accessible open shelves.

Despite the Crown's archival strategy of preserving financial documentation in central stable repositories, these archives maintained some mobility. Financial records and accounts were constantly under the scrutiny of the MCR and CRP's officers, who removed them from the archives to verify incomes and manage expenditures, frequently keeping both old and recent documents at their workplaces for extended periods. In some circumstances, and despite the existence of stable and fully operating archives, officers brought documents to their private residencies, 
creating small financial archives that the authorities later struggled to retrieve. This is the case of the various "books, accounts, justifications, judicial documents, documents and writing of the royal court" that Nicolò-after his father, the accounting master Antonio Carusio, died-was asked to return to the MCR within three days (ASPA, TRP, NP, N. 17, f. 73r, 2.5.1460). It was not just a few volumes pertaining to ongoing affairs that left the archive. Huge masses of financial records and accounts were periodically removed from the Palermo's archives and transported across the island so that the accounting masters could carry out the accounting review while following viceroys on their travels. Although at least two accounting masters were always supposed to be in Palermo, in 1460 the MCR decided to follow the viceregal court with "the most part of the accounts currently under review at our office", so that they could continue the accounting review: to facilitate this, they had the carpenter mastru Anthoni di Missina build six new chests to store the office's accounts, books, and writings, which were later transported, alongside the office's other chests, to Messina and Catania (ASPA, TRP, NP, N. 17, ff. 84v-85r, 4.6.1460), where swine and sheep had occupied the chancery.

The continuous movement of documents from and to archives seems contrary to the creation of stable collecting archives for financial documentation, but, in fact, mobility — as discussed by Markus Friedrich (2018, pp 135-138)—should be considered a typical feature of pre-modern archives. And in the case of financial archives, this feature is directly connected to the nature of the documents preserved, which were continuously subject to examination. Nor did the migration of the Kingdom of Sicily's late-medieval financial records and accounts stop with the establishment of the above-discussed Sant'Antonio and chancery house archives, for during the sixteenth-century they were initially moved to the Steri (de Vivo et al. 2016, Introduzione, doc. 7) and later to Palermo's Royal Palace. There, they lay abandoned until 1762, when they were found rotten, unbound, and scattered across various room of the palace and in private residences (de Vivo et al. 2016, Introduzione, doc. 13).

Acknowledgments I would like to thank Laura Sciascia for her invaluable insights into the late-medieval Palazzo Steri of Palermo, Sicily.

Funding This work was supported by the Beatriu de Pinós programme (2018 BP 00274), funded by the Direcció General de Recerca de la Generalitat de Catalunya and by the European Union through the COFUND programme (contract no. 801370) for Marie-Skłodowska-Curie actions in the "Horizon 2020" programme, and and by the research project 'Movement and mobility in the medieval Mediterranean. People, terms, and concepts (PGC2018-094502-B-I00), funded by the Spanish Ministry of the Science, Innovation and Universities (MICINN). Open Access funding provided thanks to the CRUE-CSIC agreement with Springer Nature.

Open Access This article is licensed under a Creative Commons Attribution 4.0 International License, which permits use, sharing, adaptation, distribution and reproduction in any medium or format, as long as you give appropriate credit to the original author(s) and the source, provide a link to the Creative Commons licence, and indicate if changes were made. The images or other third party material in this article are included in the article's Creative Commons licence, unless indicated otherwise in a credit line to the material. If material is not included in the article's Creative Commons licence and your intended use is not permitted by statutory regulation or exceeds the permitted use, you will need to obtain permission directly from the copyright holder. To view a copy of this licence, visit http://creativecommons.org/licen ses/by/4.0/. 


\section{References}

\section{Archivio di Stato di Palermo (ASPA)}

Conservatoria di Registro $=\mathrm{CR}$

Real Cancelleria $=\mathrm{RC}$

Real Segreteria $=$ RS

Rappresentanze di Palermo $=\mathrm{RP}$

Secrezia di Palermo $=\mathrm{SP}$

Tribunale del Real Patrimonio $=\mathrm{TRP}$

Numerazione Provvisoria $=$ NP

Lettere Reali $=$ LR

Lettere Viceregie $=\mathrm{LV}$

\section{Arxiu de la Corona de Aragón (ACA)}

Real Cancillería $=\mathrm{RC}$

Andenmatten B, Castelnuovo G (2008) Produzione e conservazione documentarie nel principato sabaudo, XIII-XV secolo. Bullettino dell' Istituto Storico Italiano per Il Medio Evo 110:279-348

Barberi GL (1962), Beneficia ecclesiastica, ed. by I Peri. 2 vols, Manfredi, Palermo

Blair AM, Milligan J (Eds) (2007) Toward a cultural history of archives. Special issue of Arch Sci 7(4)

Brendecke A (ed) (2015) Praktiken der frühen neuzeit: akteure-handlungen-artefakte. Böhlau, Cologne

Brendecke A (2016) The Empirical empire: Spanish colonial rule and the politics of knowledge, or. edn. 2009. De Gruyter Oldenbourg, Berlin-Boston 2016

Capasso B (2009), Historia diplomatica regni Siciliae ab anno 1250 ad annum 1266, ed. by R Pilone. Laveglia-Carlone, Manocalzati (AV), Italy.

Casanova E (1928) Archivistica, 2nd edn. Stab. arti grafiche Lazzeri, Siena

Chiarito A (1772) Comento istorico critico diplomatico sulla costituzione de instrumentis conficiendis per curiales dell'imperador Federigo II. A spese di Vincenzo Orsino, Napoli.

Clanchy MT (1993) From memory to written record. England 1066-1307, 2nd edn. Blackwell, Oxford

Conde y Delgado de Molina R (2008) Reyes y archivos en la Corona de Aragón. Siete siglos de reglamentación y praxis archivística (siglos XII-XIX). Institución Fernando el Católico, Zaragoza

Corens L, Peters K, Walsham A (eds) (2016) The social history of the archive: record keeping in Early Modern Europe. Past \& Present 230, Issue supplement 11

Corens L, Peters K, Walsham A (eds) (2018) Archives and information in the early modern world. Oxford University Press, Oxford

Crooks P (2013) Reconstructing the past: The case of the medieval Irish chancery rolls. In: Dawson NM, Larkin F (eds) Lawyers, the law and history: Irish legal history society discourses and other papers, 2006-2011. Four Courts Press, Dublin, pp 281-309

D'Arcangelo P (2021), Il signore va alla Camera. I relevi dell'archivio della regia camera della sommaria. In: Senatore F (ed) La signoria rurale nell'Italia del tardo medioevo, vol. 2, Archivi e poteri feudali nel Mezzogiorno (secoli XIV-XVI). Firenze University Press, Firenze, pp 153-248

de Vivo F (2010) Ordering the archive in Early Modern Venice (1400-1650). Arch Sci 10(3):231-248

de Vivo F (2013) Cœur de l'État, lieu de tension: Le tournant archivistique vu de Venise (XVe-XVIIe siècle). Annales Histoire, Sciences Sociales, 68(3):699-728

de Vivo F, Guidi A, Silvestri A (2016a) Archival transformations in Early Modern European history. Eur Hist Q 46(3):421-434

de Vivo F, Guidi A, Silvestri A (2016b) Archival transformations in early modern Europe. Special Issue of Eur Hist Q 46(3):421-434

de Vivo F, Guidi A, Silvestri A (eds) (2016c) Fonti per la storia degli archivi degli antichi Stati italiani. Ministero dei beni e delle attività culturali e del turismo, Direzione generale archivi, Roma

Della Vigna P (1786) Consitutiones regum regni utriusque Siciliae, mandante Friderico II imperatore. Ex regia typographia, Napoli 
Donato MP (ed) (2018) Archives, record keeping and imperial governance, 1500-1800. Special Issue of $\mathrm{J}$ of Early Mod Hist 22(5)

Donato MP, Saada A (eds) (2019) Pratiques d'archives à l'époque moderne: Europe, mondes coloniaux. Classiques Garnier, Paris

Dover MP (2007) Deciphering the diplomatic archives of fifteenth-century Italy. Arch Sci 7(4):297-316

Enzensberger H (2002) Chanceries, charters, and administration in Norman Italy. In: Loud GA, Metcalfe A (eds) The Society of Norman Italy. Brill, Leiden, pp 117-150

Ferorelli N (1912) L'Archivio camerale. Annuario del Regio Archivio di Stato in Milano per l'anno 1911:123-154

Friedrich M (2018) The birth of the archive: A history of knowledge, or. edn. 2013. University of Michigan Press, Ann Arbor

Giardina C (ed) (1937) Capitoli e privilegi di Messina. Regia deputazione di storia patria per la Sicilia, Palermo

Giuffrida R (1956), L'archivio del tribunale del real patrimonio e la sua funzione di archivio centrale del regno di Sicilia alla fine del secolo XVIII. Archivio Storico Siciliano ( $3^{\text {rd }}$ series), VIII: 260-282

Gregorio R (1791) Bibliotheca scriptorum qui res in Sicilia gestas sub Aragonum imperio retulere. 2 vols, Ex Regio Typographeo, Palermo

Head RC (2003) Knowing like a State: the transformation of political knowledge in Swiss archives, 1450-1770. J Mod Hist 75(4):745-782

Head RC (2010) Archival knowledge cultures in Europe, 1400-1900. Special Issue of Arch Sci 10(3)

Head RC (2019) Making archives in Early Modern Europe: Proof, information, and political record-keeping, 1400-1700. Cambridge University Press, Cambridge

Hughes A (2016) The accounts of the kingdom: memory, community and the English civil war. Past \& Present 230(supp111):311-329

Ketelaar E (2006) The panoptical archive. In: Blouin FX, Rosenberg WG (eds) Archives, documentation, and institutions of social memory: Essays from the Sawyer seminar. The University of Michigan Press, Ann Harbor, pp 144-150

Kiesewetter A (1998) La cancelleria angioina. In: L'Etat Angevin. Pouvoir, culture et société entre XIII e XIV siècle. Ecole Française de Rome, Roma, pp 361-415

La Mantia G (ed) (1918) Codice diplomatico dei re aragonesi di Sicilia. Scuola tipografica boccone del povero, Palermo

Leverotti F (2008) L'archivio dei Visconti signori di Milano. Reti Medievali Rivista 9. https://doi.org/ $10.6092 / 1593-2214 / 101$

López Rodríguez C (2018) La serie dei registros Neapolis dell'Archivio de la Corona de Aragón. In: López Rodríguez C, Palmieri S (eds) I registri privilegiorum di Alfonso il Magnanimo della serie Neapolis dell'Archivio della Corona d'Aragona. Accademia Pontaniana, Napoli, pp XI-XLIV

Palmieri S (2002), L'archivio della Regia Zecca. Formazione, perdite documentarie e ricostruzione. In: S Palmieri, Degli archivi napoletani: storia e tradizione. Il Mulino, Napoli, pp 321-353.

Rück P (1977) L'ordinamento degli archivi ducali di Savoia sotto Amedeo VIII (1398-1451), or. edn. 1971. Spoleto, Arti grafiche Panetto \& Petrelli

Salamone L (1997) La numerazione provvisoria del tribunale del real patrimonio nell'Archivio di Stato di Palermo. Archivio Storico Messinese 73:5-94

Schwartz JM and Cook T (eds) (2002) Archives, records, and power. Special issue of Arch Sci 2(1-2)

Sciuti Russi V (1983) Astrea in Sicilia: il ministero togato nella società siciliana dei secoli XVI e XVII. Jovene, Napoli

Senatore F (ed) (2021) La signoria rurale nell'Italia del tardo medioevo Archivi e poteri feudali nel Mezzogiorno (secoli XIV-XVI), vol 2. Firenze University Press, Firenze

Serci S (2016) Gli archivi dell'amministrazione centrale del Regno di Sardegna tra XIV e XV secolo: testimonianze documentarie e ipotesi di lavoro. Archivi 11(1):41-74

Silvestri A (2016) Archives of the mediterranean. governance and record-keeping in the Crown of Aragon in the long fifteenth century. Eur His Q 46(3):435-457

Silvestri A (2018) L'amministrazione del regno di Sicilia: cancelleria, apparati finanziari e strumenti di governo nel tardo medioevo. Viella, Roma

Silvestri A (2020) Too much to account for The Crown of Aragon and the collapse of the auditing system in late-medieval Sicily. Account Hist Rev 30(2):171-206

Soll J (2014) The reckoning: Financial accountability and the rise and fall of nations. Basic Books, New York 
Soll J (2018) Jean-Baptiste Colbert, Accounting, and the genesis of the state archive in early modern France. In: Corens L, Peters K, Walsham A (eds) Archives and information in the early modern world. British Academy, United Kingdom, pp 87-101

Sthamer EH (1911) Die reste des archivs Karls I. von Sizilien im Staatsarchiv zu Neapel. Quellen und forschungen aus Italien. Archiven Und Bibliotheken 14:69-139

Stoler AL (2002) Colonial archives and the arts of governance. Arch Sci 2(1-2):87-109

Takayama H (1993) The administration of the Norman Kingdom of Sicily. Brill, Leiden-New York

Tanzini L (2008) Una pratica documentaria tra sovrabbondanze e silenzi: i regolatori e le scritture d'ufficio a Firenze tra XIV e XV secolo. Reti Medievali Rivista 9. https://doi.org/10.6092/1593$2214 / 104$

Trasselli C (1954) L'archivio del patrimonio del regno di Sicilia. Prima nota su un riordinamento in corso. Rassegna degli Archivi di Stato 14:106-127

Vivo de F, Guidi A, Silvestri A (eds) (2015) Archivi e archivisti in Italia tra medioevo ed età moderna. Viella, Roma

Walsham A (2016) The social history of the archive: recordkeeping in Early Modern Europe. Past \& Present 230(supp111): 9-48

Publisher's Note Springer Nature remains neutral with regard to jurisdictional claims in published maps and institutional affiliations.

Alessandro Silvestri After obtaining the PhD from the Università degli Studi di Milano (2012), Alessandro Silvestri held various postdoctoral positions in Ireland, Italy, and the United Kingdom. He is currently a Beatriu de Pinós fellow at the Institució Milà i Fontanals de Recerca en Humanitats (CSIC) in Barcelona and a member of the consolidated research group 'The Crown of Aragon, Islam, and the Mediterranean World' (CAIMMed), recognised by the Government of Catalonia (2017 SGR 109). He is author of the monograph 'L'amministrazione del regno di Sicilia. Cancelleria, apparati finanziari e strumenti di governo nel tardo medioevo' (Roma, 2018), as well as of various book chapters and journal articles dedicated to accounting, record-keeping, information management, and archival history in Sicily and the Crown of Aragon of the later Middle Ages.

\section{Authors and Affiliations}

\section{Alessandro Silvestri ${ }^{1}$}

Alessandro Silvestri

alessansilvestri@gmail.com; a.silvestri@imf.csic.es

1 Institució Milà i Fontanals de Recerca en Humanitats (CSIC), C/ Egipcíaques 15, 08001 Barcelona, Spain 